\title{
Dynamics of Land Surface Temperature in Response to Land Cover Changes in Lagos Metropolis
}

\author{
Obiefuna J. N., ${ }^{1}$ Nwilo P. C., ${ }^{2}$ Okolie C. J., ${ }^{2}$ Emmanuel E. I. ${ }^{2}$ and Daramola O. \\ E. ${ }^{2, *}$ \\ ${ }^{1}$ Department of Architecture, Enugu State University of Science and Technology, Enugu, Enugu State, Nigeria \\ ${ }^{2}$ Department of Surveying and Geoinformatics, Faculty of Engineering, University of Lagos, Akoka, Lagos \\ State, Nigeria \\ Corresponding Author: *eodaramola@unilag.edu.ng
}

\begin{abstract}
Land Surface Temperature (LST) is one of the key environmental parameters affected by land cover change. Lagos State has been experiencing an increase in surface temperature due to growing areas of impervious surfaces caused by anthropogenic urban sprawl. While the change in LST has been established, its continuous monitoring and relationship with continuing Land Cover (LC) changes have become imperative for appropriate management and policy actions. This study investigated the effect of land cover change on LST in the rapidly urbanising Lagos metropolis. Using spatio-temporal Landsat imageries with their thermal bands and ancillary data, land cover and LST changes were assessed from 1984 - 2015. The spatial patterns of LST and LC were derived to examine the response of LST to urban growth. Findings confirmed urban sprawl in previously rural areas northward of the metropolis in LGAs such as Ikorodu, Kosofe and those fringing the state's border with Ogun State. This also confirmed new growth areas as occurring west of the metropolis in Amuwo-Odofin LGA. The results further showed that the rapid urbanisation in Lagos metropolis has altered the surface thermal environment as indicated by increased LST. Built-up area and bare land accounted for the highest increase in LST (as high as $1.5^{\circ} \mathrm{C}$ in some areas) while wetlands and other vegetated areas played a vital role in moderating the surface temperature in areas they still occupy. This provides reasonable evidence for the appropriate authorities to institute requisite policies and actions towards moderating urban sprawl while ramping up the development of urban green infrastructure to counter global warming.
\end{abstract}

Keywords: Landsat imageries, land cover changes, land surface temperature, urbanisation, GIS, Lagos metropolis

\subsection{Introduction}

In the past two decades, many studies have deployed satellite thermal remote sensing data in the derivation of land surface temperature (LST) for urban areas (Deng et al., 2018; Tarawally et al., 2018; Jeevalakshmi et al., 2017; Zaharadden et al., 2016; Oguz, 2013; Nwilo et al., 2012; Srivastava et al., 2009; David, 2008; Xiao et al., 2007; Zhang et al., 2006; Jimenez-Munoz and Sobrino, 2003). This is owing in part to LST being an important parameter in many environmental and climate models (Oguz, 2013). It is one of the environmental parameters affected by land cover change due to its role in the exchange of earth's surface energy, exchange of surface matter, physical and chemical processes with the atmosphere (Deng et al., 2018; Butuc and Moldovean, 2012; Xiao et al., 2007). At the same time, Land cover (LC) change is a significant factor affecting LST. This is because the surface characteristics, reflectance and roughness of different land cover types differ markedly thereby affecting in similar ways the LST associated with them. Intense human activities with rapid urbanization worldwide alter rapidly the land cover and thus LST. In consequence, the link between LC and LST requires to be understood in order to appreciate the ecological effects of these changes. The relative warmth of cities has long been measured in a developing country like Nigeria through field observations of air temperature at discrete locations. Such measurements represent point 
measurements not area estimates of thermal conditions (Zaharaddeen et al., 2016; Obinna et al., 2013). However, medium resolution remote sensing data offering repetitive spatial and temporal coverage have become ready tools to document both LST and LC changes. In this regard, three methods widely used for retrieving LST from imageries include the Single-channel method, Splitwindow method, Temperature and Emissivity Separation (TES) method. Of these, the Single-channel method utilizes only one thermal band and thus is suitable for sensors such as Landsat TM, ETM+ and OLI, each having one thermal band (Oguz, 2013).

Lagos metropolis in Lagos State is a former Federal capital and the current economic capital of Nigeria. It is recognized as one of the megacities of the world undergoing rapid urbanization and urban sprawl (Obiefuna et al., 2013). A previous study (Nwilo et al., 2012) has established changing LST for the state and metropolis between 1984 and 2006. With continuing global warming coupled with unrestrained urban sprawl and in-fill, continuous monitoring to generate reliable estimates of LST and LC changes are crucial for appropriate management and policy actions at the metropolitan level for the well-being of residents of the metropolis. This study therefore investigated changes in LST and LC between 1984 and 2015 with the aim of determining their spatial distribution as well as the relationship between them.

\subsection{Study area}

The study area comprises of seventeen Local Government Areas (LGAs) in Lagos metropolis. A map of Lagos State showing the metropolis is shown in Figure 1. Lagos is the largest and most complex urban area in Nigeria (Kafewo, 2016). Lagos was the former capital of Nigeria and is the country's centre of commerce. The state has a very diverse and fast-growing population resulting from unrelenting migration to it from all parts of Nigeria as well as neighbouring countries. The metropolitan area of the state lies between Latitudes $6^{\circ} 20^{\prime} 00^{\prime \prime}-6^{\circ} 42^{\prime} 10^{\prime \prime} \mathrm{N}$ and Longitudes $3^{\circ} 02^{\prime} 30^{\prime \prime}-$ $3^{\circ} 42^{\prime} 40$ "E. It comprises the following LGAs' - Agege, Ajeromi/Ifelodun, Alimosho, Amuwo Odofin, Apapa, Eti-Osa, Ifako/Ijaye, Ikeja, Ikorodu, Kosofe, Lagos Island, Lagos Mainland, Mushin, Ojo, Oshodi/Isolo, Shomolu, and Surulere.

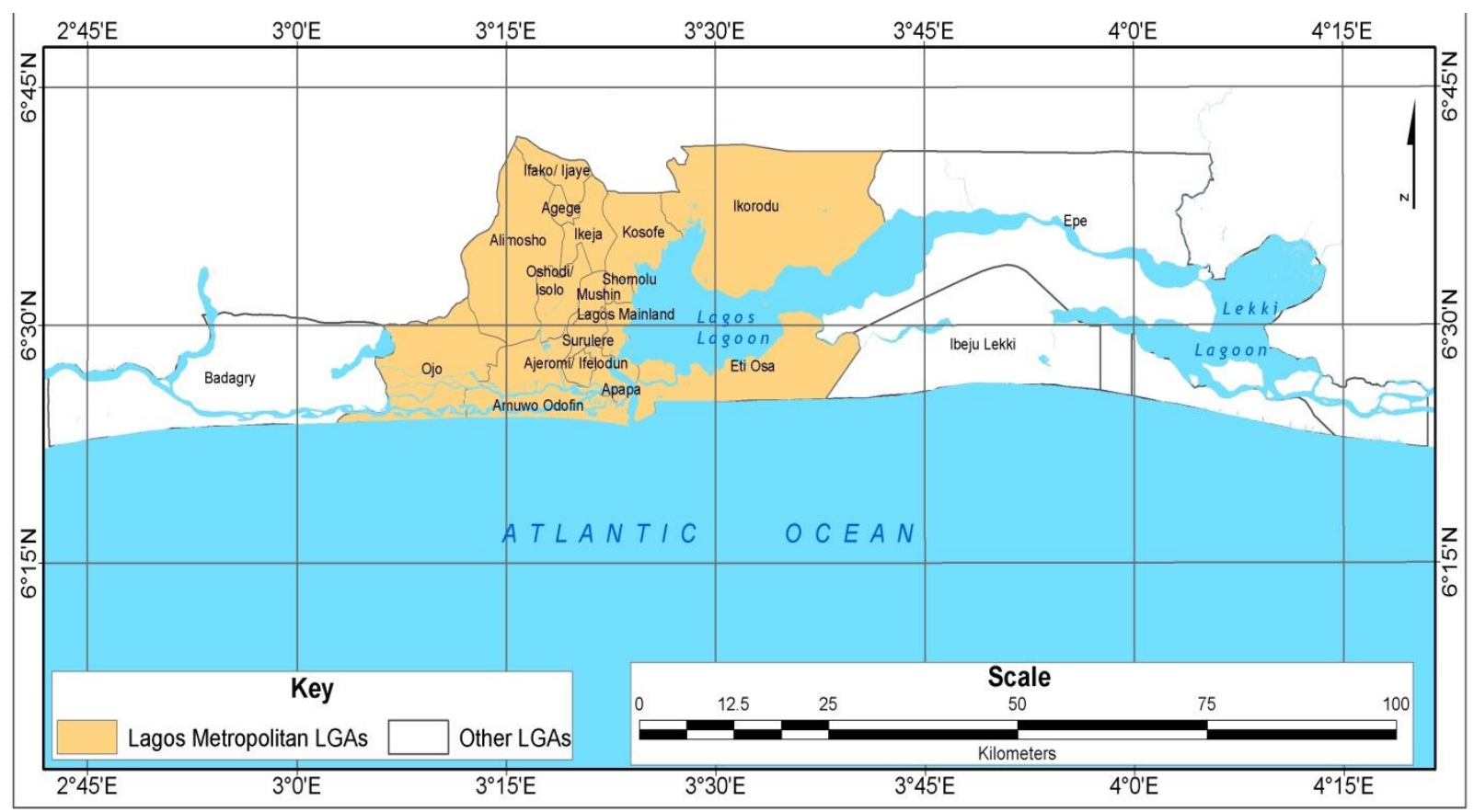

Figure 1: Map of Lagos State showing the LGAs in the metropolis.

Lagos metropolis in Lagos State is recognised as one of the megacities of the world undergoing rapid urbanisation and urban sprawl (Obiefuna et al., 2013). The growth of population in the metropolis has assumed a geometrical progression, while the provision of urban infrastructure and housing to meet this demand is not at commensurate level (Olugbenga and Adekemi, 2013). Plate 1 shows a view 
symptomatic of a densely built-up area in Alimosho LGA while Plate 2 illustrates the congestion and seeming inadequacy of transportation infrastructure in parts of the metropolis.

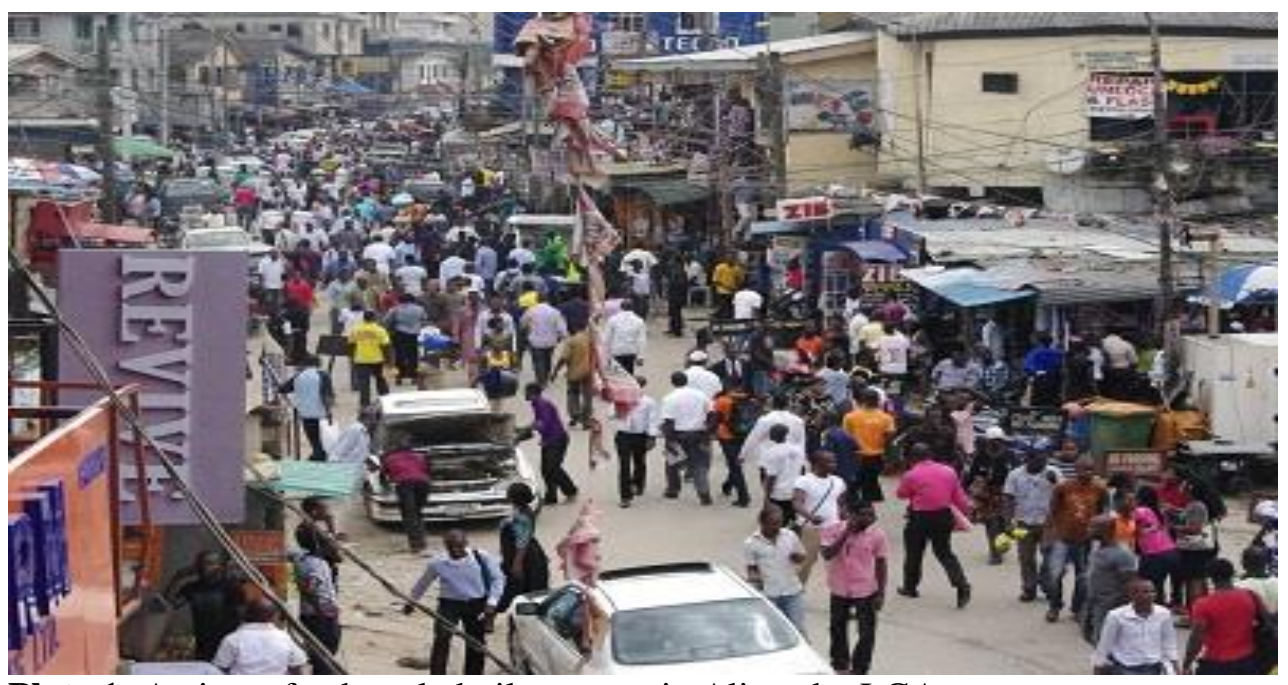

Plate 1: A view of a densely built-up area in Alimosho LGA (Source: Business Day, 2014)

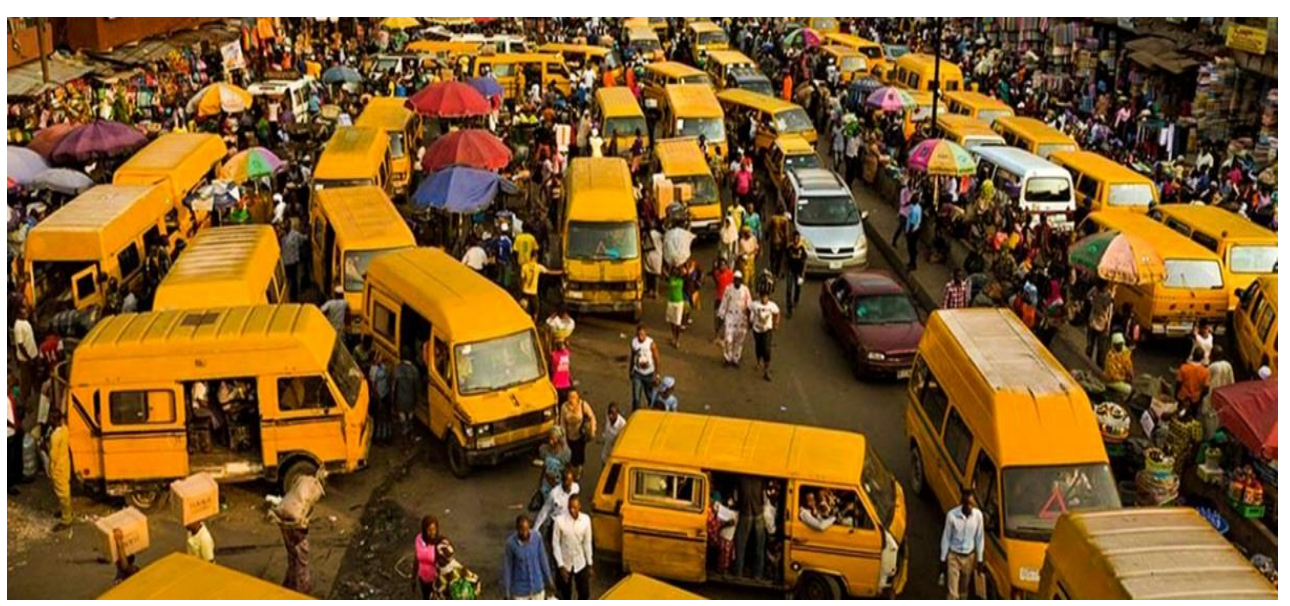

Plate 2: Commuters throng a bus park along a thoroughfare at Ifako-Ijaiye LGA (Source: Ifako-Ijaiye LGA Online publication, 2018).

\subsection{Methodology}

The methodology adopted in this research consisted of data acquisition, datum harmonisation, land cover (LC) extraction, land surface temperature (LST) determination, generation of LST inventory and link with LC. These steps are discussed in the following sections.

\subsection{Data acquisition}

This study utilised imageries from Landsat 5 Thematic Mapper (TM) of 1984 and Landsat 8 Operational Land Imager (OLI) Thermal Infrared Sensor of 2015 acquired from the United States Geological Surveys (USGS) Global Visualisation online portal - http://glovis.usgs.gov. The Landsat mission is a joint initiative between the USGS and the National Aeronautics and Space Administration (NASA). It represents the world's longest continuously acquired collection of spacebased medium-resolution land remote sensing data. A gazetteer of town and community locations was also acquired from the National Population Commission (NPopC). To overcome measurement and geometry computation difficulties, all datasets in different formats and projections were harmonized to fit into a uniform coordinate system - WGS84 UTM Zone 31N. Table 1 summarises the characteristics of the Landsat datasets used for the land surface temperature determination. 
Table 1: Characteristics of the Landsat scenes used for LST determination

\begin{tabular}{|l|l|l|l|l|}
\hline Landsat Sensor & Year & $\begin{array}{l}\text { Path/ Row } \\
\text { No }\end{array}$ & Acquisition Date & $\begin{array}{l}\text { Acquisition Time } \\
(\mathrm{GMT}+1)\end{array}$ \\
\hline $\begin{array}{l}\text { Landsat 5 Thematic Mapper (TM) - } \\
\text { Band 6 }\end{array}$ & 1984 & $191 / 55$ & $18-12-84$ & $10: 33: 04$ AM \\
\hline $\begin{array}{l}\text { Landsat 8 Thermal Infrared Sensor } \\
\text { (TIRS) - Band 10 }\end{array}$ & 2015 & $191 / 55$ & $06-01-15$ & $11: 02: 59$ AM \\
\hline
\end{tabular}

\subsection{Datum harmonisation}

All the layers used for the production of the land cover and land surface temperature maps were projected onto a Universal Transverse Mercator (UTM) coordinate system (Zone 31N) on WGS84 datum. This projection helped to overcome linear measurement difficulties and preserve geometric properties of the maps.

\subsection{Land cover extraction}

The preliminary interpretation of the Landsat imageries involved categorising the study area land cover into five classes, namely: bare land, built-up area, wetlands, mixed forests and water bodies. Next, a step-by-step process of training class selection based on the spectral signatures of each class and ancillary data was done with ENVI 5.0 software. Care was taken to avoid inclusion of mixed pixels in the training classes so as not to compromise the fidelity of the output classes. Then, supervised classification of the imageries was performed using the parallelepiped technique. The parallelepiped algorithm is a computationally efficient method of classifying remotely sensed data. It uses a simple decision rule to classify multispectral data. The decision boundaries form an $n$ dimensional parallelepiped in feature space (Kumar, 2003). If a pixel value lies above the low threshold and below the high threshold for all $n$ bands being classified, it is assigned to that class. If the pixel value falls in multiple classes, ENVI assigns the pixel to the first class matched. After classification, the feature classes were transferred to ArcGIS 10.4 for editing, elimination of spurious clusters and refinement of the output.

\subsection{Land surface temperature determination}

This study relied on the following thermal bands - TM band 6 and TIRS band 10 for land surface temperature retrieval of Lagos State metropolis. The Digital Number values on the imagery were converted to radiance, then to at-sensor (top-of-atmosphere) brightness temperature and further, to land surface temperature (LST) in order to draw quantitative analysis from thermal remote sensing data. The procedure is as follows:

\subsubsection{Conversion of digital number to spectral radiance}

For Landsat 5 and 7, the formula to convert Digital Number (DN) to radiance is given by Zareie et al. (2016):

$$
L_{\lambda}=\left(\frac{L M A X-L M I N}{Q C A L M A X-Q C A L M I N}\right) \times(Q C A L-Q C A L M I N)+L M I N
$$

where:
$L_{\lambda}$
$Q C A L$
Spectral radiance at the sensor's aperture (Watts $/\left(\mathrm{m}^{2} . \mathrm{sr} . \mu \mathrm{m}\right)$
LMIN
Quantized calibrated pixel value in DN
LMAX
Spectral radiance scaled to QCALMIN
QCALMIN
Spectral radiance scaled to QCALMAX
QCALMAX
Minimum quantized calibrated pixel value (corresponding to LMIN) in DN
Maximum quantized calibrated pixel value (corresponding to LMAX) in DN.

For Landsat 8, the following formula was used to derive the spectral radiance (USGS, 2015):

$L_{\lambda}=M_{L} \times Q C A L+A_{L}$

where:

$M_{L} \quad$ Radiance multiplicative scaling factor for the band

$A_{L} \quad$ Radiance additive scaling factor for the band

NB: LMIN, KMAX, QCALMIN, QCALMAX, $M_{L}$ and $A_{L}$ are sourced from the Landsat metadata file. 


\subsubsection{Conversion of spectral radiance to top-of-atmosphere brightness temperature}

After the spectral radiance, $L_{\lambda}$ was computed; the brightness temperature at the satellite level was directly calculated by using the following approximation formula (Schott and Volchok 1985; Wukelic et al., 1989; Goetz et al, 1995; Qin et al., 2001; Zareie et al., 2016):

$T=K_{2} / \log \left(1+K_{1} / L_{\lambda}\right)$

where:

$T \quad$ Top of Atmosphere Brightness Temperature (deg K)

$K_{l}\left(\mathrm{Wcm}^{-2} \mathrm{sr}^{-1} \mu \mathrm{m}^{-1}\right)$ and $K_{2}(\mathrm{deg} \mathrm{K})$ are pre-launch calibration constants.

Values for $\mathrm{K}_{1}$ and $\mathrm{K}_{2}$ for Landsat TM and ETM+ are shown in Table 2, while Table 3 shows the values for Landsat 8 TIRS.

Table 2: Landsat TM and ETM+ thermal band calibration constants

\begin{tabular}{|l|c|c|}
\hline & Landsat 5 TM & Landsat 7 ETM+ \\
\hline $\mathrm{K}_{1}\left(\mathrm{Wcm}^{-2} \mathrm{sr}^{-1} \mu \mathrm{m}^{-1}\right)$ & 607.76 & 666.09 \\
\hline $\mathrm{K}_{2}(\operatorname{deg} \mathrm{K})$ & 1260.56 & 1282.71 \\
\hline
\end{tabular}

(Source: Ghulam, 2010)

Table 3: Landsat 8 TIRS thermal band calibration constants

\begin{tabular}{|l|c|c|}
\hline & Band 10 & Band 11 \\
\hline $\mathrm{K}_{1}\left(\mathrm{Wcm}^{-2} \mathrm{sr}^{-1} \mu \mathrm{m}^{-1}\right)$ & 774.89 & 480.89 \\
\hline $\mathrm{K}_{2}(\mathrm{deg} \mathrm{K})$ & 1321.08 & 1201.14 \\
\hline
\end{tabular}

\subsubsection{Conversion of brightness temperature to land surface temperature}

The equation for conversion from brightness temperature to land surface temperature follows (Weng et al., 2004; Cummings, 2007; Zareie et al., 2016).

$S_{T}=\frac{T}{1+(\lambda \times T / \rho) \log \varepsilon}$

where:

$S_{T} \quad$ Land surface temperature (deg K)

$\lambda \quad$ Wavelength of emitted radiance $(11.5 \mu \mathrm{m})$,

$\varepsilon \quad$ Land surface emissivity (typically 0.95 )

$\rho \quad h * c / \sigma=1.438 * 10^{-2} \mathrm{mK}\left(\sigma=\right.$ Boltzmann constant $=1.38 * 10^{-23} \mathrm{~J} / \mathrm{K}, \mathrm{h}=$ Planck's constant $=6.626 * 10^{-34} \mathrm{Js}, \mathrm{c}=$ velocity of light $\left.=2.998 * 10^{8} \mathrm{~m} / \mathrm{s}\right)$.

Finally, the land surface temperature in degrees Kelvin was converted to Celsius by subtracting from 273.15 .

\subsection{Generation of land surface temperature inventory and link with LC}

An inventory of land surface temperature was created for the metropolis from the above steps for each period. Then, a point shapefile of 512 community locations was overlaid on the land surface temperature maps in the ArcGIS environment. Next, using the 'Extract values to Points' tool in ArcGIS Spatial Analyst, the temperature values on the maps coinciding with the community locations were extracted and appended to the attribute tables of the shapefiles. The temperatures at communities within each LGA were then averaged to generate the mean temperatures in each LGA. Similarly, the land cover classes coinciding with the community locations were extracted for a point-to-point comparison with the point temperatures. To explore the relationship between LST and LC, descriptive statistics was used. The mean LST and its standard deviation for each land cover class were calculated with the Statistical Package for Social Sciences (SPSS) for the two periods of 1984 and 2015. 


\subsection{Results and Discussion}

Table 4 shows the coverage area of the land cover classes for 1984 and 2015 while Figures 2 and 3 show the land cover and land surface temperature maps for the same time periods respectively.

Table 4: Coverage area of land cover classes in Lagos Metropolis

\begin{tabular}{|r|l|c|c|c|c|}
\hline S/N & \multirow{2}{*}{ Feature Class } & \multicolumn{2}{|c|}{1984} & \multicolumn{2}{c|}{2015} \\
\cline { 3 - 6 } & & Area $\left(\mathrm{km}^{2}\right)$ & Area $(\%)$ & Area $\left(\mathrm{km}^{2}\right)$ & Area $(\%)$ \\
\hline 1 & Bare land & 104.58 & 6.55 & 35.48 & 2.19 \\
\hline 2 & Built up area & 133.04 & 8.33 & 859.50 & 53.15 \\
\hline 3 & Water body & 301.27 & 18.86 & 295.68 & 18.28 \\
\hline 4 & $\begin{array}{l}\text { Wetlands (including mangroves and } \\
\text { swamps) }\end{array}$ & 293.13 & 18.35 & 230.21 & 14.24 \\
\hline 5 & Mixed forests & 733.43 & 45.90 & 196.28 & 12.14 \\
\hline 6 & Cloud cover & 32.32 & 2.02 & - & - \\
\hline \multicolumn{2}{|c|}{ Total } & 1597.76 & 100.00 & 1617.17 & 100.00 \\
\hline
\end{tabular}

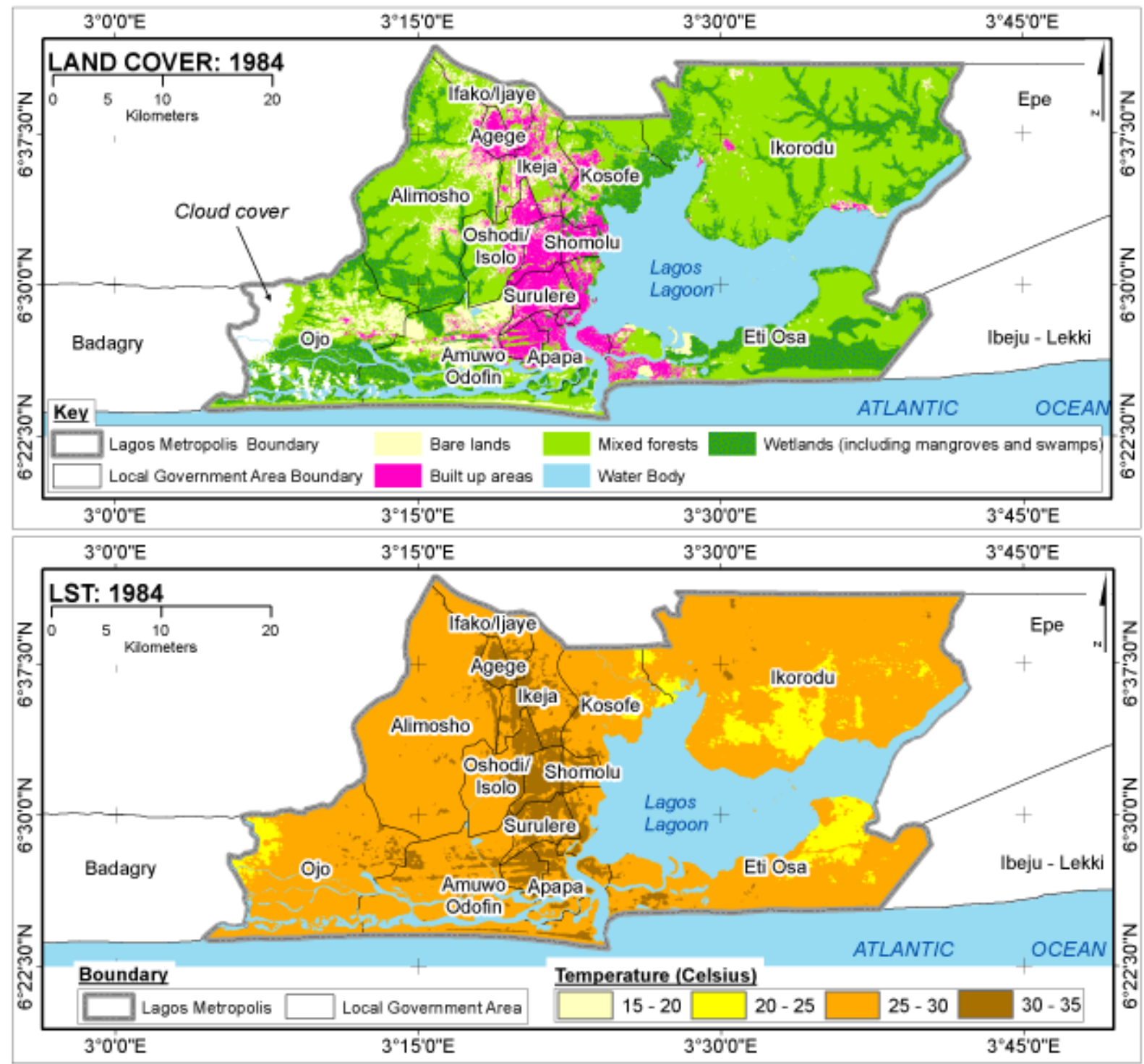

Figure 2: Lagos metropolis 1984 - Land Cover map (top); Land Surface Temperature map (bottom).

There is a general increase in the coverage of built-up area between 1984 and 2015 from $133.04 \mathrm{~km}^{2}$ to $859.50 \mathrm{~km}^{2}$, a gain of $726.46 \mathrm{~km}^{2}$ at $23.43 \mathrm{~km}^{2} \mathrm{yr}^{-1}$. Within the same period, wetlands and mixed forests decreased from $293.13 \mathrm{~km}^{2}$ to $230.21 \mathrm{~km}^{2}$ and $733.43 \mathrm{~km}^{2}$ to $196.28 \mathrm{~km}^{2}$ respectively. There was a significant increase in the land surface area of the metropolis in 2015 perhaps due to expansion of the metropolis through land reclamation activities in the Eko Atlantic City and other areas. Within this same period $(1984-2015)$, bare lands decreased from $104.58 \mathrm{~km}^{2}$ to $35.48 \mathrm{~km}^{2}$, and water bodies 
decreased from $301.27 \mathrm{~km}^{2}$ to $295.68 \mathrm{~km}^{2}$. Cloud cover accounted for $2.02 \%$ of the coverage area of the imagery in 1984.

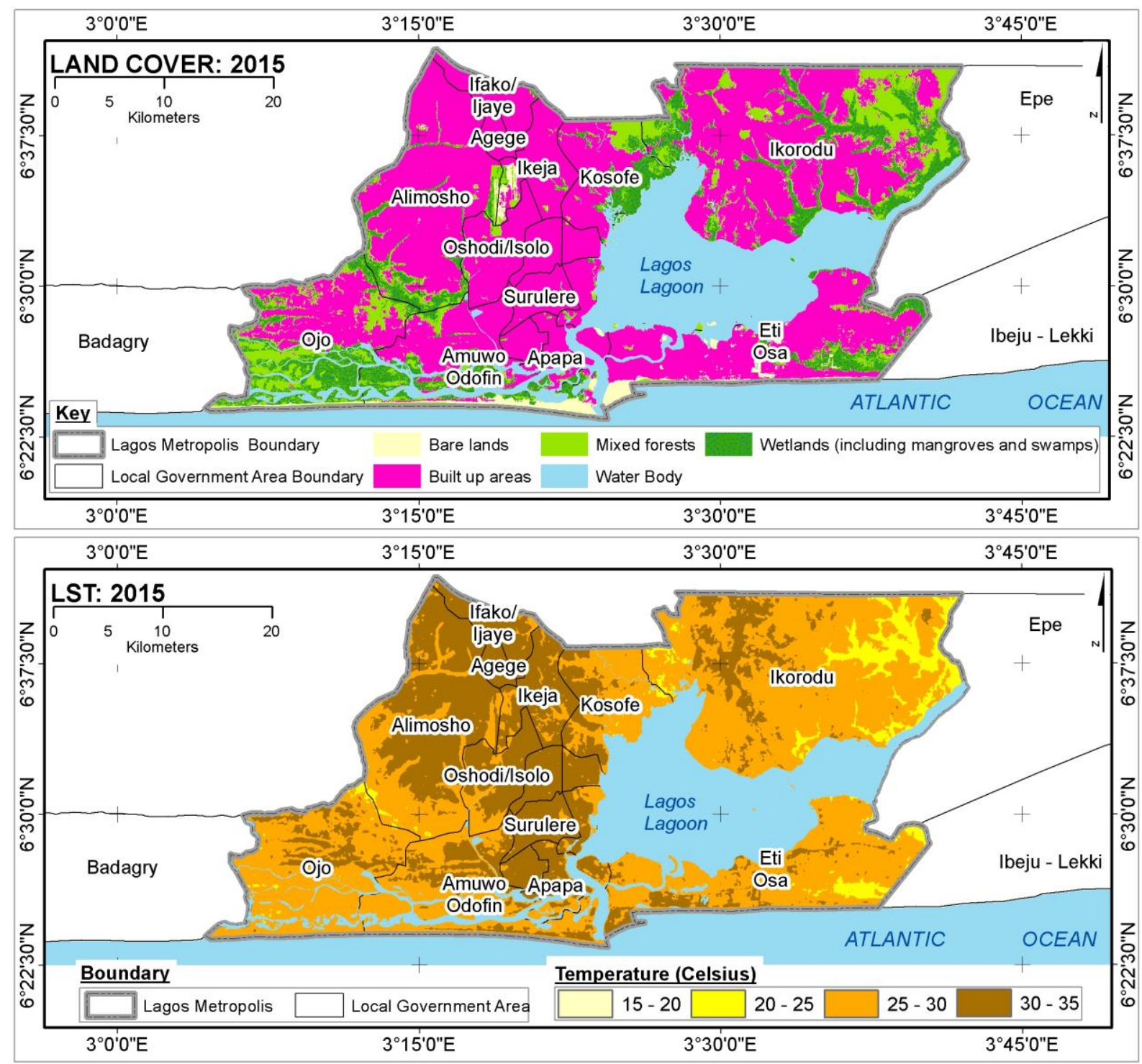

Figure 3: Lagos metropolis 2015 - Land Cover map (top); Land Surface Temperature map (bottom).

Table 5 shows the changes in mean land surface temperatures (LST) from 1984-2015 in the seventeen Local Government Areas (LGAs) of the metropolis. There is a general trend of increasing surface temperatures from 1984-2015. The highest increases in mean land surface temperature occurred in Alimosho LGA $\left(2.812^{\circ} \mathrm{C}\right)$, Ikorodu LGA $\left(2.320^{\circ} \mathrm{C}\right)$, Ifako Ijaiye LGA $\left(2.314^{\circ} \mathrm{C}\right)$, and Eti-Osa LGA $\left(2.071^{\circ} \mathrm{C}\right)$. Within the same period, the lowest increases occurred in the following LGAs: Lagos Island $\left(0.049^{\circ} \mathrm{C}\right)$, Shomolu $\left(0.579^{\circ} \mathrm{C}\right)$, Amuwo Odofin $\left(0.633^{\circ} \mathrm{C}\right)$, and Lagos Mainland $\left(0.735^{\circ} \mathrm{C}\right)$. Figure 4 presents a graphical illustration of this change in mean land surface temperatures at the various LGAs from 1984-2015. 
Table 5: Mean Land Surface Temperatures in the 17 LGAs of Lagos Metropolis (1984-2015).

\begin{tabular}{|r|l|c|c|c|c|}
\hline \multicolumn{2}{|c|}{ S/N } & \multirow{2}{*}{$N^{*}$} & \multicolumn{2}{c|}{ Mean Land Surface Temperature $\left({ }^{\circ} \mathrm{C}\right)$} & \multirow{2}{*}{$\mathrm{B}-\mathrm{A}\left({ }^{\circ} \mathrm{C}\right)$} \\
\cline { 4 - 5 } & & & $1984(\mathrm{~A})$ & $2015^{* *}(\mathrm{~B})$ & \\
\hline 1 & Agege & 20 & 30.843 & 32.319 & 1.476 \\
\hline 3 & Ajeromi/Ifelodun & 15 & 32.108 & 32.978 & 0.870 \\
\hline 4 & Alimosho & 64 & 28.495 & 31.307 & 2.812 \\
\hline 5 & Apapa & 31 & 29.283 & 29.916 & 0.633 \\
\hline 6 & Eti-Osa & 7 & 30.654 & 31.393 & 0.739 \\
\hline 7 & Ifako Ijaiye & 38 & 27.382 & 29.453 & 2.071 \\
\hline 8 & Ikeja & 9 & 29.158 & 31.472 & 2.314 \\
\hline 9 & Ikorodu & 22 & 30.077 & 31.52 & 1.443 \\
\hline 10 & Kosofe & 23 & 27.683 & 30.003 & 2.320 \\
\hline 11 & Lagos Island & 14 & 30.653 & 30.356 & 1.703 \\
\hline 12 & Lagos Mainland & 16 & 30.235 & 30.572 & 0.049 \\
\hline 13 & Mushin & 23 & 31.51 & 30.97 & 0.735 \\
\hline 14 & Ojo & 52 & 27.585 & 29.107 & 0.772 \\
\hline 15 & Oshodi/Isolo & 25 & 30.803 & 32.054 & 1.522 \\
\hline 16 & Shomolu & 19 & 31.143 & 31.722 & 1.251 \\
\hline 17 & Surulere & 10 & 30.67 & 31.992 & 0.579 \\
\hline
\end{tabular}

*N-No. of sample points

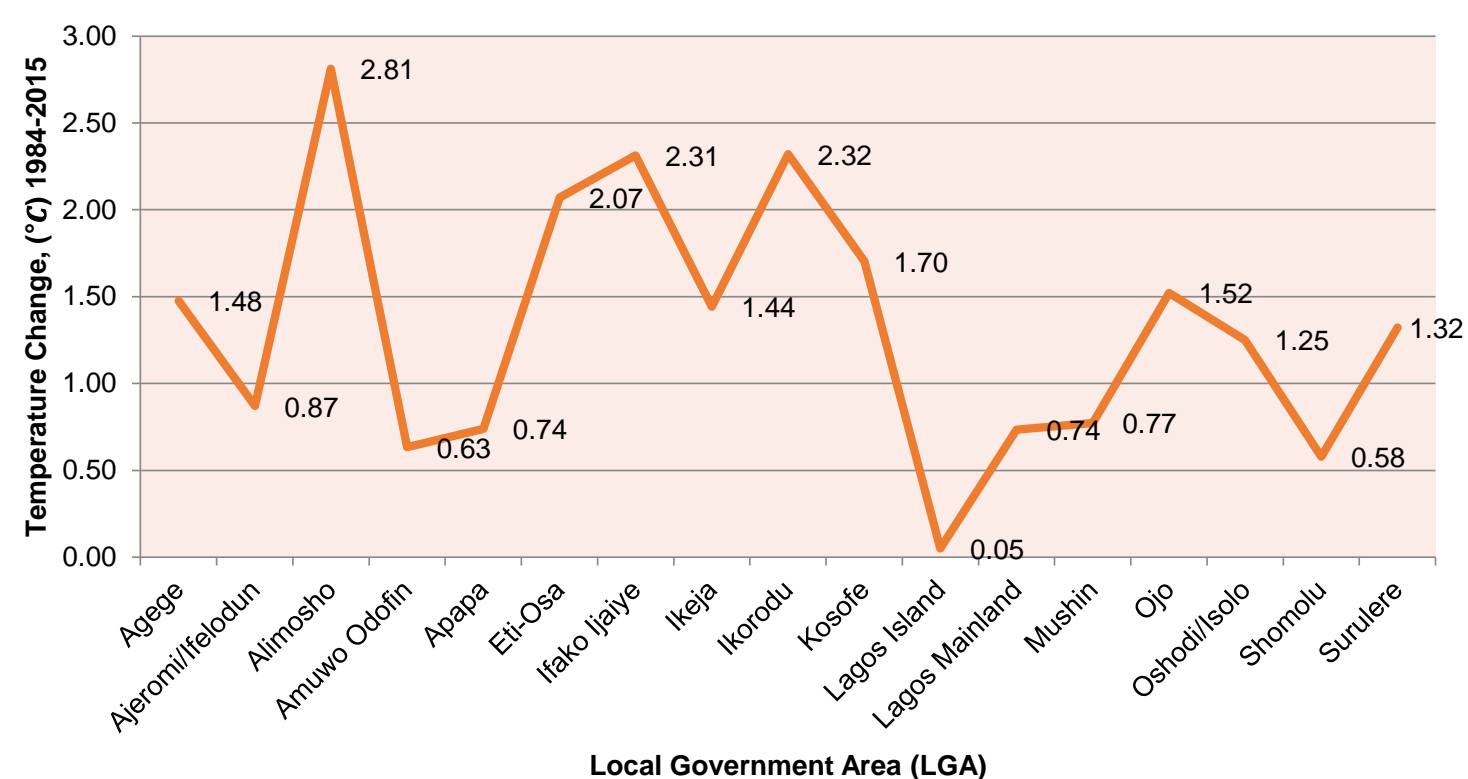

Figure 4: Change in mean land surface temperatures at LGAs from 1984-2015.

Table 6 shows the coverage of built-up area and bare land in the four LGAs with highest temperature changes from 1984-2015. In the table, positive values indicate a net gain while negative values indicate a net loss. The highest increase in built-up area was in Ikorodu LGA $\left(220.53 \mathrm{~km}^{2}\right)$. Similarly, the lowest decrease in bare lands occurred in the same Ikorodu LGA $\left(3.42 \mathrm{~km}^{2}\right)$. Alimosho LGA had the highest loss of bare lands $\left(15.53 \mathrm{~km}^{2}\right)$.

Table 6: Coverage of Built-up area and bare land in the four LGAs with highest temperature changes (1984-2015).

\begin{tabular}{|r|l|c|c|c|c|c|c|}
\hline \multirow{2}{*}{ S/N } & LGA & \multicolumn{2}{|c|}{$\begin{array}{c}\text { Bare land } \\
\text { Area }\left(\mathrm{km}^{2}\right)\end{array}$} & \multirow{2}{*}{$\begin{array}{c}\text { Area of change } \\
\left(\mathrm{km}^{2}\right)\end{array}$} & \multicolumn{2}{c|}{$\begin{array}{c}\text { Built up area } \\
\text { Area }\left(\mathrm{km}^{2}\right)\end{array}$} & $\begin{array}{c}\text { Area of change } \\
\left(\mathrm{km}^{2}\right)\end{array}$ \\
\cline { 3 - 4 } \cline { 6 - 7 } & & 1984 & 2015 & & 1984 & 2015 & \\
\hline 1 & Alimosho & 16.84 & 1.31 & -15.53 & 4.10 & 146.13 & 142.04 \\
\hline 2 & Eti-Osa & 6.85 & 13.41 & 6.55 & 9.06 & 126.09 & 117.02 \\
\hline 3 & Ifako Ijaiye & 6.78 & 0.01 & -6.77 & 3.21 & 25.82 & 22.61 \\
\hline 4 & Ikorodu & 3.91 & 0.49 & -3.42 & 2.27 & 222.80 & 220.53 \\
\hline
\end{tabular}

Tables 7 and 8 show the descriptive statistics of the mean LST and standard deviation for each LC class for both 1984 and 2015 respectively. In 1984, the mean temperatures for each land cover class 
are namely: bare land $\left(29.61^{\circ} \mathrm{C}\right)$, built-up area $\left(30.69^{\circ} \mathrm{C}\right)$, wetlands $\left(27.92^{\circ} \mathrm{C}\right)$ and mixed forests $\left(27.63^{\circ} \mathrm{C}\right)$. In 2015 they were: bare land $\left(29.78^{\circ} \mathrm{C}\right)$; built-up area $\left(30.92^{\circ} \mathrm{C}\right)$, wetlands $\left(27.20^{\circ} \mathrm{C}\right)$, and mixed forests $\left(27.48^{\circ} \mathrm{C}\right)$. The mean LST for all land cover types in 1984 was $28.98^{\circ} \mathrm{C}$ while it was $30.68^{\circ} \mathrm{C}$ in 2015 indicating an increase of $1.7^{\circ} \mathrm{C}$ in mean LST over the metropolis.

Table 7: Descriptive statistics of Land cover and LST relationship - 1984

\begin{tabular}{|l|r|r|r|r|r|r|}
\hline & & \multicolumn{5}{|c|}{ LST $\left({ }^{\circ} \mathrm{C}\right)$} \\
\hline LC Class & $N^{*}$ & Mean & Std. Deviation & Std. Error & Min. & Max. \\
& & & & & & \\
\hline Bare land & 52 & 29.61 & 0.995 & 0.138 & 26.90 & 31.59 \\
\hline Built-up Area & 187 & 30.69 & 1.155 & 0.085 & 26.25 & 32.86 \\
\hline Wetlands & 53 & 27.92 & 1.598 & 0.219 & 25.56 & 32.13 \\
\hline Mixed Forests & 220 & 27.63 & 1.424 & 0.096 & 23.75 & 30.41 \\
\hline Total & 512 & 28.98 & 1.934 & 0.085 & 23.75 & 32.86 \\
\hline
\end{tabular}

Table 8: Descriptive statistics of Land cover and LST relationship - 2015.

\begin{tabular}{|l|r|r|r|r|r|r|}
\hline & & \multicolumn{5}{|c|}{ LST $\left({ }^{\circ} \mathrm{C}\right)$} \\
\hline LC Class & $N^{*}$ & Mean & Std. Deviation & Std. Error & Min. & Max. \\
& & & & & & \\
\hline Bare land & 4 & 29.78 & 1.156 & .578 & 28.55 & 31.34 \\
\hline Built-up Area & 475 & 30.92 & 1.194 & .055 & 26.79 & 33.40 \\
\hline Wetlands & 18 & 27.20 & .916 & .215 & 25.76 & 29.08 \\
\hline Mixed Forests & 15 & 27.48 & 1.149 & .297 & 26.21 & 30.26 \\
\hline Total & 512 & 30.68 & 1.477 & .065 & 25.76 & 33.40 \\
\hline
\end{tabular}

$N^{*}-$ No. of sample points.

The land cover change in the period under study is in tandem with findings of rapid urbanization in earlier studies on the area by Obiefuna et al. (2013), and Okude and Adelumiluyi (2006). It also affirms that most of the urban development occurred on areas of ecological assets of wetlands and mixed forests as these witnessed massive decline. In 1984 , areas with temperature of $30-35^{\circ} \mathrm{C}$ were mainly already built-up LGAs of Apapa, Ikeja, Somolu, Surulere and Agege. The average temperature range for other LGAs was $25-30^{\circ} \mathrm{C}$. However in 2015 , the temperature range of $30-35^{\circ} \mathrm{C}$ has spread to hitherto rural LGAs which have become built-up such as Alimosho, Eti-osa, Ifako Ijaiye and Ikorodu. Table 5 further shows that generally surface temperature increased across the entire metropolis in 2015 with the exception of Lagos Island LGA. Also, it indicates that the already builtup LGAs in 1984 such as Shomolu and Apapa recorded a minimum LST change of about $0.58^{\circ} \mathrm{C}$ in 2015. The increase in the mean LST of $1.7^{\circ} \mathrm{C}$ in 2015 over the previous period further points to a warming surface temperature across the metropolis. The relationship between LC change and LST is revealed as highlighted in Tables 7 and 8. Four LGAs' (Alimosho, Eti-osa, Ifako Ijaiye and Ikorodu) with temperature range of $25-30^{\circ} \mathrm{C}$ in 1984 have all gained over $2^{\circ} \mathrm{C}$ in 2015 just as their built-up areas and impervious surfaces grew by at least 8-10 times in the same period. Moreover, this relationship is further exposed by the mean LST of both the built-up area and bare land. The mean LST for built-up area with its high anthropogenic activities and high albedo is higher than that of other LC classes in the two periods. In displaying an increase of $0.23^{\circ} \mathrm{C}$ in 2015 , it signifies that aside global warming; this is closely aligned with the rapidly expanding metropolis. The mean LST of ecological assets of mixed forests and wetlands which were even lower than the average mean LST in 1984 further dropped lower than this mean in 2015. With lower albedo, this suggests that their moderating effect on surface temperature should be increased in the metropolis through more open space and green infrastructure projects.

\subsection{Conclusion}

The study has investigated changes in LC and LST between 1984 and 2015 through the use of remote sensing data. It established that rapid urbanization is continuing in the metropolis mostly on the fringe and rural LGAs' where land is expectedly cheaper. Also, it established that surface temperature is generally rising in the metropolis in the study period. Additionally, it established that the areas of increased LST in the metropolis coincided with areas of rapid increase in built-up area. Increased surface temperature across the metropolis therefore necessitates the suggestion for the state authorities 
to ramp-up the development of the city's open space and urban green infrastructure projects which appear to have stalled in recent years. The findings on increasing LST require to be validated with insitu measurements stretching over a number of years. Also, in-situ measurements of LST in areas of industrial cluster such as Apapa, Ijora Ilupeju and Ikeja are important towards determining the contribution of these clusters to overall LST of the metropolis especially in view of the dwindling manufacturing activities.

\section{References}

Business Day (2014). Lagos may require N20bn for new computer village. [Online]. Available at: https://www.businessdayonline.com/exclusives/article/lagos-may-require-n20bn-for-new-computervillage/ [Accessed 12 Sept. 2018].

Butuc, B.R. \& Moldovean G., (2011). Environmental impact scenario of an azimuthal tracked PV platform based on $\mathrm{CO}_{2}$ emissions reduction. Environmental Engineering and Management Journal, 10, pp. 271-276.

Cummings, S. (2007). An Analysis of Surface Temperature in San Antonio, Texas. Term Project. EES5053/ES4093: Remote Sensing, UTSA.

David, A.R. (2008). A re-interpretation of Landsat TM data on Chernobyl. International Journal of Remote Sensing, 10 (8), pp. 1423-1427.

Deng, Y., Shijie, W., Xiaoyong, B., Yichao, T., Luhua, W., et al (2018). Relationship among land surface temperature and LUCC, NDVI in typical karst area. Scientific Reports, (2018), 8: 641, 12pps.

Ghulam, A. (2010). Calculating Surface Temperature using Landsat thermal imagery. [Online] Available at: https://serc.carleton.edu/files/NAGTWorkshops/gis/activities2/student handout calculating te.pdf [Accessed 25 March. 2016].

Goetz, S.J., Halthore, R. N., Hall, F.G. \& Markham, B.L. (1995). Surface temperature retrieval in temperate grassland with multiresolution sensors. Journal of Geophysical Research, 100(25), pp. 397410.

Ifako-Ijaye LG (2018). Welcome to Ifako Ijaiye Local Government.[Online]. Available at: http://ifakoijaiye.lg.gov.ng/welcome-to-ifako-ijaiye-local-govt/ [Accessed 12 Sept. 2018].

Jeevalakshmi. D., Narayana Reddy, S. \& Manikiam, B. (2017). Land surface temperature retrieval from Landsat data using Emissivity Estimation. International Journal of Applied Engineering Research, ISSN 0973-4562, 12 (20), pp. 9679-9687.

Jimenez-Munoz J.C. \& Sobrino J.A. (2003). A generalized single-channel method for retrieving land surface temperature from remote sensing data. Journal of Geophysical Research, 108

Kafewo, A.E. (2016). An Assessment of the methods of car parking in Lagos State, Nigeria. M.Sc. Thesis, Department of Geography, Ahmadu Bello University, Zaria. [Online]. Available at: http://kubanni.abu.edu.ng/jspui/bitstream/123456789/9975/1/AN\%20ASSESSMENT\%20OF\%20TH E\%20METHODS\%20OF\%20CAR\%20PARKING\%20IN\%20LAGOS\%20STATE\%2C\%20NIGERI A.pdf [Accessed 10 Sept. 2018].

Kumar, M. (2003). Digital Image Processing. In Satellite Remote Sensing and GIS Applications in Agricultural Meterology, edited by Sivakumar, M.V.K., Roy, P.S., Harmsen, K., and Saha, S.K., Proceedings of the WMO Training Workshop, July 2003.AGM-8, WMO/TD, 1182. 
Nwilo, P.C., Olayinka, D.N., Obiefuna, J.N., Atagbaza, A.O. \& Adzandeh, A.E. (2012). Determination of Land Surface Temperature (LST) and Potential Urban Heat Island Effect in Parts of Lagos State using Satellite Imageries. FUTY Journal of the Environment, 7 (1), pp. 19-33

Obiefuna, J.N., Nwilo, P.C., Atagbaza, A.O. \& Okolie, C.J. (2013). Land cover dynamics associated with changes in the wetlands of Lagos/Lekki Lagoon system of Lagos, Nigeria. Journal of Coastal Research, 29 (3), pp. 671-679.

Obinna, C., Anejionu, F. I., Okeke, E. C., Moka, V. \& Uzondinma, N. (2013). Mapping Spatiotemporal Variations of Land Surface Temperature in South East Nigeria with Landsat. GeoSpatial Applications, pp. 1-14.

Olugbenga, E. \& Adekemi, O. (2013). Challenges of Housing Delivery in Metropolitan Lagos. Research on Humanities and Social Sciences, 3 (20), ISSN2222-2863, pp. 1-9

Oguz, H. (2013). LST Calculator: a program for retrieving land surface temperature from Landsat TM/ETM+ imagery. Environmental Engineering and Management Journal, 12 (3), pp. 549 - 555.

Okude, A.S. \& Ademiluyi, L.A. (2006). Implications of the changing pattern of land cover of the Lagos coastal area of Nigeria. American-Eurasian Journal of Scientific Research, 1(1), pp. 31 - 37.

Qin, Z., Karnieli, A. \& Berlinier, P. (2001). A Mono-window Algorithm for retrieving Land Surface Temperature from Landsat TM data and its application to the Israel-Egypt border region. International Journal of Remote Sensing, 22 (18), pp. 3719-3746.

Schott, J. R. \& Volchok, W. J. (1985). Thematic Mapper thermal infrared calibration. Photogrammetric Engineering and Remote Sensing, 51, pp. 1351-1357.

Srivastava P.K., Majumdar T.J. \& Bhattacharya A.K. (2009). Surface temperature estimation in Singhbhum Shear Zone of India using Landsat-7 ETM+ thermal infrared data. Advances in Space Research, 43, pp. 1563 - 1574.

Tarawally, M., Wenbo, X., Weiming, H. \& Terence, D.M. (2018), Comparative Analysis of Responses of Land Surface Temperature to Long-Term Land Use/Cover Changes between a Coastal and Inland City: A Case of Freetown and Bo Town in Sierra Leone, Remote Sensing 2018, 10 (112), pp. 1-18

United States Geological Survey, USGS. (2015), Landsat 8 (L8) Data Users Handbook, Version 1.0. LSDS-1574. Department of the Interior, U.S. Geological Survey.

Weng, Q., Lu, D. \& Schubring, J. (2004). Estimation of land surface temperature - vegetation abundance relationship for urban heat island studies. Remote Sensing of Environment, 89 (4), pp. 467 -483 .

Wukelic, G. E., Gibbons, D. E., Martucci, L. M., and Foote, H. P., (1989). Radiometric calibration of Landsat Thematic Mapper Thermal Band. Remote Sensing of Environment, 28, pp. 339-347.

Xiao R., Ouyang Z., Zheng H., Li W., Schienke E.W., Wang X., (2007). Spatial pattern of impervious surfaces and their impacts on land surface temperature in Beijing, China. Journal of Environmental Sciences, 19, pp. 250-256.

Zareie, S., Khosravi, H. \& Nasiri, A. (2016). Derivation of Land Surface Temperature from Landsat Thematic Mapper (TM) sensor data and analysing relation between Land Use changes and Surface Temperature. Solid Earth. Discuss. doi:10.5194/se-2016-22, 201. 
Zaharaddeen, I., Ibrahim I.B. \& Zachariah, A. (2016), Estimation of land surface temperature of Kaduna metropolis, Nigeria using Landsat images. Science World Journal, 11 (3), ISSN 1597-6343, pp. $36-42$.

Zhang J., Wang Y. \& Li Y., (2006), A C++ program for retrieving land surface temperature from the data of Landsat TM/ETM+ band 6, Computers \& Geosciences, 32, pp. 1796-1805.

Zhang, Y., Balzter, H., Liu, B. \& Chen, Y. (2016). Analyzing the Impacts of Urbanization and Seasonal Variation on Land Surface Temperature Based on Subpixel Fractional Covers Using Landsat Images. IEEE Journal of Selected Topics in Applied Earth Observations and Remote Sensing, 10 (4), pp. 1344-1356. 